\title{
Gaya Kepemimpinan Direktur Utama, Disiplin Kerja dan Motivasi Kerja Terhadap Kinerja Karyawan
}

\author{
Wulan Purnamasari ${ }^{1}$, Moch Dawud Syaifudin ${ }^{2}$ dan Mukti Ali ${ }^{3}$ \\ ${ }^{123}$ Manajemen, Universitas Maarif Hasyim Latif, Megare Ngelom, Sidoarjo, Indonesia 61257 \\ Correspondence: Wulan Purnamasari (wulan_purnamasari@dosen.umaha.ac.id) \\ Received: 050821 - Revised: 060821 - Accepted: 060821 - Published: 280921
}

\begin{abstract}
Abstrak. Didalam penelitian ini terdapat maksud identifikasi pengaruh peran gaya kepemimpinan direktur utama, kinerja karyawan, disiplin kerja dan motivasi kerja pada kinerja karyawan pada PT. X Surabaya. Didalam penelitian ini menggunakan 53 responden karyawan yang memiliki pekerjaan dengan jabatan tetap pada PT. X Surabaya karena menggunakan metode purposive sampling. Pengolahan data pada penelitian ini menggunakan metode statistika Patrial Least Square (PLS) dalam proses pengujian hipotesis dan pengaruh dari variabel - variabel yang ada, seperti gaya kepemimpinan Direktur utama (gaya kepemimpinan partisipatif, gaya kepemimpinan delegatif dan gaya kepemimpinan otoriter), disiplin kerja (hubungan kemanusiaan, teladan kepemimpinan dan sanksi hukum) dan motiovasi kerja (kebutuhan akan keselamatan, keamanan, kebutuhan sosial dan juga kebutuhan fisik) kinerja karyawan (kualitas kerja dan kuantitas kerja)

Hasil dari penelitian didapatkan dari T-Statistic dan P-Value dengan presentase nilai $(<0.05)$ maka dari data tersebut diperoleh variabel gaya kepemimpinan Direktur utama pada motivasi kerja $(0,462)$, variabel gaya kepemimpinan Direktur utama pada kinerja karyawan $(0,387)$, motivasi kerja pada kinerja karyawan $(0,388)$, disiplin kerja pada motivasi kerja (0.525) dan disiplin kerja pada kinerja karyawan (0.034). Dan didapatkan kesimpulan hasil yaitu yang berpengaruh positif signifikan adalah disiplin kerja pada kinerja karyawan pada perolehan presentase di bawah p-value $(0,05)$ yaitu
\end{abstract} $(0,034)$

Kata kunci: Disiplin Kerja, Motivasi Kerja, Gaya Kepemimpinan Direktur Utama Kinerja Karyawan

Citation Format: Purnamasari. W. Syaifudin, M.D, Ali. M. (2021). Gaya Kepemimpinan Direktur Utama, Disiplin Kerja dan Motivasi Kerja Terhadap Kinerja Karyawan. Prosiding Seminar Nasional Abdimas Ma Chung (SENAM), 2020, 125-133 


\section{PENDAHULUAN}

Melalui perencanaan SDM yang optimal, akan produktivitas kerja karyawan bisa mengalami peningkatan. Hal ini dapat terwujud melalui proses penyesuaian.

Seperti peningkatan kepemimpinan Direktur utama, motivasi kerja dan disiplin kerja yang baik. Sehinga organisasi didalam corporate bisa menghasilkan apa yang ingin dicapai corporate tersebut. Dan didalam Organisasi corporate terdapat pengaruh gaya kepemimpinan pemimpin.

Gaya kepemimpinan seorang pemimpin suatu corporate secara umum memiliki prinsip dan cara tersendiri ketika bertindak, dalam memimpin dan menggerakan corporate tersebut supaya menjadi efektif. Karena sifat leadership yang dimiliki pemimpin merupakan ciri khas yang ada pada diri seorang pemimpin, karena sifat pemimpin yang satu dengan pemimpin yang lainya memiliki orientasi dan daya pemikiran yang relatif beragam dan berbeda. Oleh karena itu berhasil atau tidaknya pemimpin dalam memimpin suatu corporate dapat dilihat dari tanggung jawab dan tugas yang dikerjakan oleh organisasi yang terdapat didalamnya, karena didalam corporate tersebut terdapat konektivitas antara pemimpin dengan bawahanya

Motivasi kerja merupakan keadaan pribadi seseorang atau individu yang terdorong keinginannya untuk melakukan suatu kegiatan guna mencapai tujuan tertentu. Dan merupakan hasil sebuah proses yang bersifat internal atau eksternal bagi seorang individu yang menyebabkan timbulnya sikap antusiasme dan persistensi dalam hal melaksanakan kegiatan-kegiatan tertentu.

Disiplin kerja merupakan media atau cara yang digunakan pimpinan untuk berkomunikasi dengan karyawan supaya mereka mau dan bersedia dalam mengubah suatu tindakan atau perilaku serta mediator untuk meningkatkan kesadaran dan kesediaan seseorang untuk mentaati dan menjalankan peraturan dan norma-norma sosial yang ada dan berlaku didalam organisasi corporate tersebut. Menjadikan suatu sikap, tingkah laku dan peraturaan yang sesuai dengan peraturan bak tertulis maupun tidak tertulis. Kinerja karyawan merupakan hasil kerja dan perilaku kerja yang telah dicapai dalam menyelesaikan tugas- tugas dan tanggung jawab yang diberikan dalam satu priode tertentu. Dan merupakan pencapaian atas tujuan organisasi dalam bentuk kuantitatif atau kualitatif, kreatifitas dan fleksibilitas yang dapat diandalkan ataupun perihal lain yang menjadi keinginan organisasi corporate tersebut. 


\section{METODE PELAKSANAAN}

\section{Metode Penelitian}

Jenis penelitian pada penelitian ini adalah penelitihan survei, dimana peneliti

melakukan observasi, dengan pengumpulan data dengan cara peneliti melakukan pencatatan data yang terjadi apa adanya, dengan cara penafsiran dan penganalisaan data tersebut.

\section{Variabel Penelitian dan Pengukurannya}

Operasional variabel pada penelitian merupakan unsur penelitian yang terkait dengan variabel yang terdapat dalam judul penelitian atau yang tercakup dalam paradigma penelitian sesuai dengan hasil perumusan masalah. Aspek yang diteliti dalam penelitian ini meliputi:

1. Variabel bebas (Independen variable)
a. Kepemimpinan Direktur utama (X1)
b. Disiplin kerja (X2)

2. Variabel terikat (Dependen variabel)
a. Kinerja Karyawan (Y)

3. Variabel Intervening

a. Motivasi Kerja (Z)

\section{Metode dan Penentuan Populasi dan Sampel}

Populasi di penelitian ini yang dipilih penelitih adalah jumlah karyawan didalam corporate sebanyak 80 karyawan. Dalam pengambilan sampel sesuai populasi diatas maka peneliti menggunakan metode sampel purposive sampling. Menurut Sugiono (2018). Purposive sampling adalah teknik untuk menentukan sampel penelitian dengan beberapa pertimbangan tertentu yang bertujuan agar data yang diperoleh nantinya bisa lebih representatif. Maka dari itu peniliti mengambil anggota sampel dari populasi dengan pemilahan karakter khusus yaitu karyawan tetap dan didapat dari sebagian karyawan tetap di PT. X Surabaya sebanyak 52 orang.

\section{Prosedur Pengumpulan Data}

Teknik pengumpulan data pada penelitian ini mengunakan:
a. Study Pustaka
b. Studi Lapangan
c. Penyebaran Kuisioner 
d. Wawancara

\section{Pengukuran Data}

Penelitian ini pengukuran datanya memakai skala Likert.

\section{Metode Analisis}

Adapun metode yang dipergunakan dalam penelitian inimenggunakan metode penelitian Struktural Equation Modeling (SEM) dengan menggunakan alat analis Partial Least Square (PLS) dengan aplikasi smart PLS 2.03.

\section{HASIL DAN PEMBAHASAN}

Didalam uji Bootstrapping didalamnya akan mengetahui pengaruh secara langsung atau tidak langsung dari variabel ke variabel lainya. Berikut ini gambar dari Bootstrapping dengan Smart PLS 3.0

\section{Uji Cronbach Alpha}

Uji Cronbach Alpha merupakan tempat dimana uji Reliability dan Validity didalamnya. Dengan keterangan apabilah nilai indikator konstruk yang ada pada setiap variabel memiliki nilai lebih dari 0,6 maka variabel tersebut dapat dinyatakan reliabel.

Berikut hasil olah data menggunakan Smart PLS 3.0

Tabel 1. Cronbach Alpha

\begin{tabular}{cc}
\hline & Cronbach Alpha \\
\hline $\mathrm{X} 1$ & 0.934 \\
$\mathrm{X} 2$ & 0.912 \\
$\mathrm{Z}$ & 0.901 \\
$\mathrm{Y}$ & 0.909 \\
\hline
\end{tabular}

\section{Uji Composite Reliability}

Uji Composite Reliability merupakan sebuah uji yang diproses pada Smart PLS untuk menguji suatu reliabilias variabel dengan tolak ukur dari hasil nilai Composite Reliability dari blok indikator yang mengukur nilai variabel. Hasil olah data sebagai berikut:

Dari data tabel 4.1 diatas dapat dilihat bahwa nilai dari setiap variabel diatas 0.6 dengan artian variabel yang ada dikatakan reliabel.

Tabel 2. Composite Reliability 
Composite Reliability

\begin{tabular}{ccc}
\hline X1 & 0.929 \\
\hline X2 & 0.925 \\
\hline Z & 0.924 \\
\hline Y & 0.922
\end{tabular}

Composite Reliability merupakan kelompok indikator yang mengukur suatu variabel yang terdapat reliabilitas komposit yang baik jika memiliki composite reliability lebih dari 0.7 meskipun bukan standart absolute.

Uji AVE (Average Variance Extracted)

Tabel 3.AVE (Average Variance Extracted)

\begin{tabular}{ccc}
$\mathrm{X} 1$ & 0.598 \\
\hline $\mathrm{X} 2$ & 0.579 \\
\hline $\mathrm{Z}$ & 0.581 \\
\hline $\mathrm{Y}$ & 0.577
\end{tabular}

Discriminan validity merupakan perbandingan nialai square roat of average variance (AVE) yang menjelaskan setiap konstruk dan korelasi antar konstruk lainya dengan model, apabila square roat of average variance (AVE) konstruk lebih besar dari korelasi dibanding keseluruhan konstruk lainya maka dapat dihasilakan Discriminan validity baik. Dengan ketentuan nilai pengukuran harus lebih dari 0.50 . 


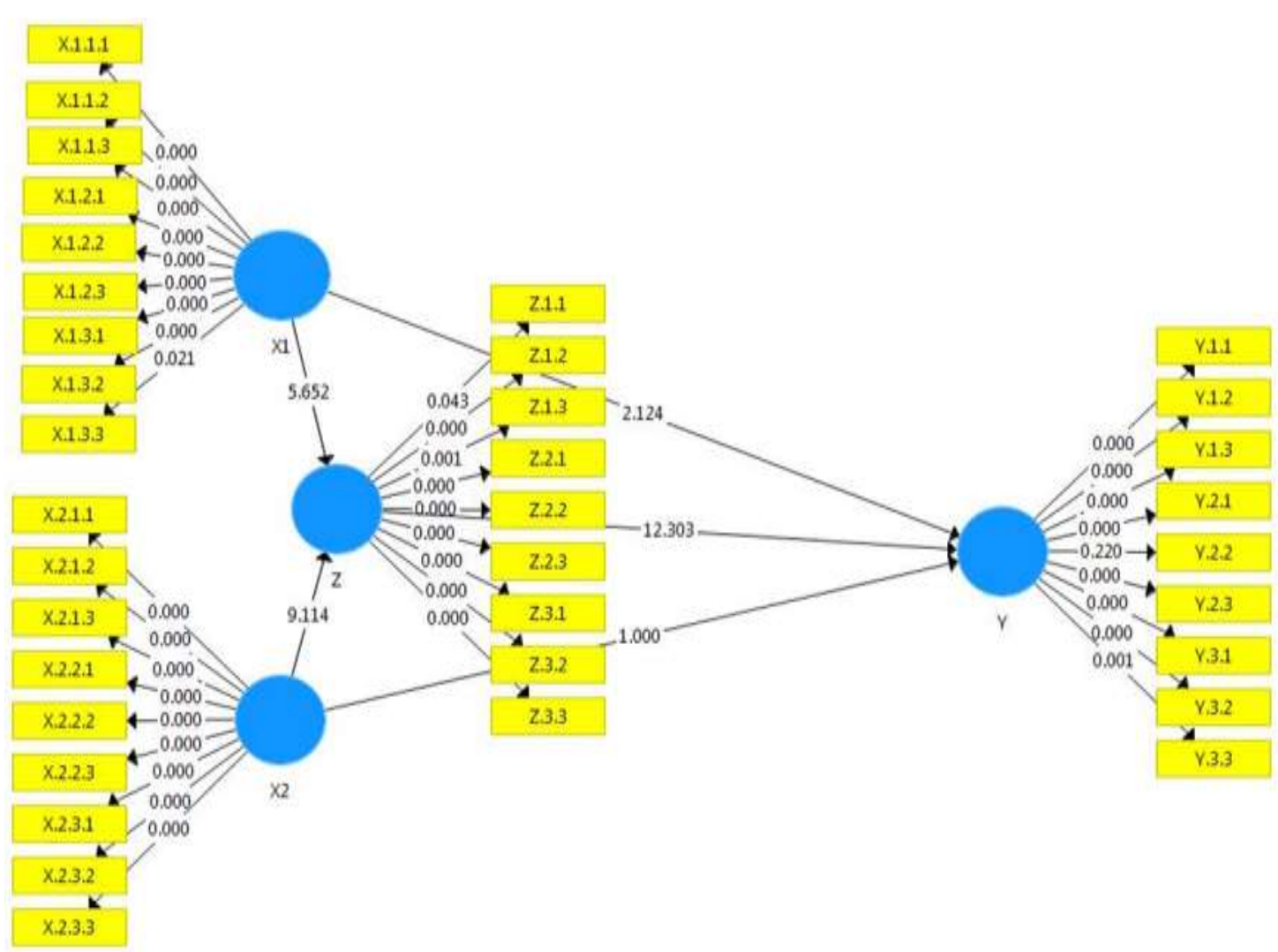

Sumber data perhitungan Smart PLS 3.0

Gambar 1. Bootstrapping

Hasil nilai sebagai berikut:

Table 4. Path Coefficients

\begin{tabular}{llllll}
\hline & $\begin{array}{l}\text { Original } \\
\text { Sample }\end{array}$ & $\begin{array}{l}\text { Sample } \\
\text { Mean }\end{array}$ & $\begin{array}{l}\text { Standart } \\
\text { Deviation }\end{array}$ & T. Statistic & P. Values \\
\hline X1-> Z & 0.288 & 0.154 & 0.390 & 0.738 & 0.461 \\
Z -> Y & 0.293 & 0.248 & 0.343 & 0.853 & 0.394 \\
X2 -> Z & -0.213 & -0.117 & 0.335 & 0.636 & 0.525 \\
X1 -> Y & 0.257 & 0.286 & 0.292 & 0.879 & 0.380 \\
X2 -> Y & -0.451 & -0.484 & 0.209 & 2.155 & 0.032 \\
\hline
\end{tabular}

Dari data tabel 4 diatas terdapat nilai jumlah besaran nilai pengaruh diantara variabel yang ada yaitu variabel intervening dan variabel terikat atau pengaruh positif dan signifikan apabilah $\mathrm{P}$ value kurang dari 0.05 atau nilai t hitung lebih besar dari t tabel (1.996). Sehinggah dapat ditarik kesimpulan sebagai berikut. 
a. Variabel Gaya Kepemimpinan Direktur Utama (GPDU) terhadap Motivasi Kerka (MK) tidak berpengaruh signifikan. Hal ini dikarenakan niali $\mathrm{p}$ value 0.461 lebih dari 0.05 dan nilai t 0.738 kurang dari 1.996 .

b. Variabel Motivasi Kerja (MK) terhadap Kinerja Karyawan (KK) tidak berpengaruh signifikan. Hal ini dikarenakan p value 0.394 lebih dari 0.05 dan nilai t 0.853 kurang dari 1.996

c. Variabel Disiplin Kerja (DK) terhadap Motivasi Kerja (MK) tidak berpengaruh signifikan. Hal ini dikarenakan p value 0.525 lebih dari 0.05 dan nilai t 0.636 kurang dari 1.996.

d. Variabel Gaya Kepemimpinan Direktur Utama (GKDU) terhadap Kinerja Karyawan (KK) tidak berpengaruh signifikan. Hal ini dikarenakan $p$ value 0.380 lebih dari 0.05 dan nilai t 0.879 kurang dari 1.996 .

e. Variabel Disiplin Kerja (DK) terhadap Kinerja Karyawan (KK) berpengaruh signifikan. Hal ini dikarenakan p value 0.03 kurang dari 0.05 dan nilai t 2.155 lebih dari 1.966.

Selain dari tabel path coefficient pengaruh tidaknya suatu variabel dapat juga dilihat dari tabel total Indirect Effect. Berikut ini olah data yang terdapat nilai tersebut.

Tabel 5. Indirect Effect

\begin{tabular}{cccccc}
\hline & $\begin{array}{c}\text { Original } \\
\text { sample }\end{array}$ & Sample Mean & $\begin{array}{c}\text { Standart } \\
\text { Deviation }\end{array}$ & T. Statistic & P. Values \\
\hline $\mathrm{X} 1->\mathrm{Z}$ & & & & \\
$\mathrm{Z}->\mathrm{Y}$ & & & & & \\
$\mathrm{X} 2->\mathrm{Z}$ & & & & \\
$\mathrm{X} 1->\mathrm{Y}$ & 0.084 & 0.0031 & 0.164 & 0.514 & 0.608 \\
$\mathrm{X} 2$-> Y & -0.062 & -0.068 & 0.131 & 0.477 & 0.633 \\
\hline
\end{tabular}

Dari tabel 5 diatas dapat disimpulkan sebagai berikut:

a. Variabel Gaya Kepemimpinan Direktur Utama (GKDU) Terhadap Kinerja Karyawan (KK) tidak memiliki hubungan Secara Langsung dikarenakan nilai p value 0.608 lebih besar dari 0.05 dan T statistik kurang dari T tabel 1.996

b. Variabel Disiplin Kerja (DK) terhadap Kinerja Karyawan (KK) tidak memiliki hubungan secara langsung dikarenakan p value 0.633 lebih dari 0.05 dan T statistik kurang dari T tabel 1.996. 
Uji hipotesis dapat digunakan perbandingan nilai $\mathrm{T}$ tabel dan $\mathrm{T}$ statistik. Jika $\mathrm{T}$ statistik lebih tinggi dibandingkan nilai $\mathrm{T}$ tabel berarti hipotesis terdukung atau diterima dan dapat diartikan berpengaruh signifikan dan positif didalam penelitian ini T-tabel yang dipergunakan adalah 2.00575 dan hasil T-statistik hasil penelitian sebagai berikut:

1. Variabel Gaya Kepemimpinan Direktur Utama (X1) terhadap Kinerja Karyawan (Y) berpengaruh positif dan signifikan dikarenakan nilai T-statistics 2.01 lebih dari Ttabel 2.00.

2. Variabel Gaya Kepemimpinan Direktur Utama (X1) terhadap Motivasi Kerja (Z) berpengaruh positif dan signifikan dikarenakan nilai T-statistics 4.78 lebih dari $\mathrm{T}$ tabel 2.00.

3. Variabel Disiplin Kerja (X2) terhadap Kinerja Karyawan (Y) tidak berpengaruh positif dan signifikan dikarenakan nilai T-statistics 0.89 kurang dari 2.00.

4. Variabel Disiplin Kerja (X2) terhadap Motivasi Kerja (Z) berpengaruh positif dan signifikan dikarenakan T-statistict 8.16 lebih dari T-tabel 2.00.

5. Variabel Motivasi Kerja (Z) terhadap Kinerja Karyawan (Y) berpengaruh positif dan signifikan dikarenakan T-statistics 10.87 lebih dari T-tabel 2.00.

\section{KESIMPULAN}

Sesuai dengan hasil analisis yang dilakukan. Maka penelitian menghasilkan kesimpulan sebagai berikut: Penelitian dilakukan dengan study lapangan, yaitu dengan menyebar kuisioner kepada 52 responden karyawan tetap PT. X Surabaya. Penelitian ini bertujuan untuk mengetahui seberapa besar pengaruh Gaya Kepemimpinan Direktur Utama (GKDU), Disiplin Kerja (DK) dan Motivasi Kerja (MK) terhadap Kinerja Karyawan (KK). Dengan menggunakan analisis hubungan antar variabe dan menggunakan metode Patrial Least Square (PLS) dengan softwere Smart PLS versi 3.0. Setelah melakukan analisis maka diperoleh hasil sebagai berikut:

Hasil uji hipotesis menunjukan adanya hubungsn signifikan antara Disiplin Kerja (DK) dengan Kinerja Karyawan (KK) maka dari itu untuk meningkatkan hasil Kinerja Karaywan (KK) pada Corporate maka perlu ditingkatkan dari segi Disiplin Kerja (DK) untuk semua belah pihak yang ada didalam perusahaan tersebut.

\section{DAFTAR PUSTAKA}

Mukhlishoh, I. (2016). Pengaruh motivasi kerja terhadap kinerja pegawai di sekretariat 
dewan perwakilan rakyat daerah (dprd) provinsi banten.

Purnamasari, W., Mardiningrum, A. L., \& Halik, A. (2019). Pengaruh Kepemimpinan Situasional, Disiplin Kerja Terhadap Motivasi Kerja dan Kinerja Karyawan Pada Yatim Mandiri. INOBIS: Jurnal Inovasi Bisnis dan Manajemen Indonesia, 2(2), 178192. https://doi.org/10.31842/jurnal-inobis.v2i2.83

Purnamasari, W. (2019). Effect Of Work Environment, Motivation Of A Work And Organizational Commitments To Performance Of Employees In Puskesmas. In Paradigma Accountancy (Vol. 2, Nomor 1). http://jurnal.narotama.ac.id/index.php/pac/

Purnamasari, W. L. D. A. I., \& Fittriya, N. L. (2019). Pengaruh Gaya Kepemimpinan, Komunikasi Internal dan Motivasi Terhadap Kinerja Karyawan Pada Perusahaan. INOBIS: Jurnal Inovasi Bisnis dan Manajemen Indonesia, 2(2), 193-205. https://doi.org/10.32493/jee.v1i3.3456

Sanjaya, R. (2018). PENGARUH MOTIVASI KERJA TERHADAP KINERJA PEGAWAI DALAM PERSPEKTIF EKONOMI ISLAM. http://repository.radenintan.ac.id/3563/1/SKRIPSI.pdf

Sumardianti. (2016). PENGARUH GAYA KEPEMIMPINAN TERHADAP MOTIVASI KERJA PEGAWAI PADA KANTOR PT. PLN (PERSERO) RAYON SUNGGUMINASA. file:///C:/Users/Admin/Downloads/SKRIPSI SUMARDIANTI.pdf

(C) 2021 by authors. Content on this article is licensed under a Creative Commons Attribution 4.0 International license. (http://creativecommons.org/licenses/by/4.0/). 